\title{
Synthesis of 1,2,3- Triazole Nucleoside Analogues
}

\author{
Pan YU, Ningning LIU, Weiyuan YUAN, Yining WEN, Qinpei WU * \\ School of Chemical Engineering and Environment, Beijing Institute of Technology, Beijing, China
}

\begin{abstract}
Both 1,2,3-triazoles and nucleosides have proved to be useful pharmacophores for antiviral and anticancer agents. A series of novel 1,2,3-triazole nucleoside analogues were designed and synthesized in order to find new antiviral or antitumor compounds.
\end{abstract}

KEYWORD: Triazole; Nucleoside; Virus; Cancer

\section{INTRODUCTION}

Cancer is one of the leading causes of death in the world, the war on cancer should never be stopped. Many nucleoside analogues have been rationally designed as anticancer drugs used in clinical therapy for both solid tumors and hematological malignancies[1], such as capecitabine[2], cladribine[3], fludarabine[4], clofarabine[5]. The structural diversity of nucleoside analogues with anticancer and antiviral activity suggests that any new nucleoside analogue is worth explored[6]. Triazole ring widely exists in the compounds with biological activity in drugs, and has been received much attention in chemistry and biochemistry.[7] Ribavirin[8], 1- $\beta$-D-ribofuranosyl-1,2,4-triazole-3carboxamide, is a broad-spectrum antiviral[9] drug that has been clinically used for treating broad DNA and RNA virus, e.g. respiratory syncytial virus, and hepatitis $\mathrm{C}$ virus [10]. Introduction of a triazole ring into nucleoside maybe improve their bioactivity for antitumor and/or antivirus [6]. A number of nucleosides with 1,2,3-triazole ring show good or excellent anticancer activity. [6] In addition, 1,2,3triazole core is stable against acidic and basic hydrolysis as well as against oxidative and reductive conditions[11], and 1,2,3 triazoles prove to be good pharmacophores in antimicrobial, antivirus [12]. According to the molecular docking experimental data, we designed and synthesized a series of triazole nucleosides described as below.

\section{RESULTS AND DISCUSSION}

The coupling of 4-methoxybenzyl azide 1 with but2-yne-1,4-diol via Huisgen [3+2] cycloaddtion reaction formed the desired triazole compound $\mathbf{2}$ in 90\% yield (Scheme 1). Using trityl protecting group, the one expected of hydroxyls in compound 2 was selectively masked to give $\mathbf{3}$ in $85 \%$ yield, which was subsequently mesylated with methanesulfonyl chloride to form $\mathbf{4}$. Treatment of $\mathbf{4}$ with purines afforded the desired nucleoside analogues 5 or $\mathbf{6}$ in good yields. The trityl group was selectively removed in the presence of TFA to give 7 or 8. Substitution of the chloro atom in $\mathbf{7}$ or $\mathbf{8}$ was smoothly carried out with amine or alkoxide to form the desired purine derivatives $9 \mathbf{a}-9 \mathrm{e}$ or $\mathbf{1 0 a}-\mathbf{1 0 e}$. Finally, the PMB was removed in net TFA under reflux and the expected triazol nucleoside derivatives were obtained in good yields. The bioactivity is still undergoing screening at present.

\section{CONCLUSIONS}

A series of novel 1,2,3-triazole nucleoside analogues were designed and synthesized successfully via seven steps with total $c a 10 \%$ yields.

Financial support of this work from the National Natural Science Foundation of China (21172019) is appreciated. 

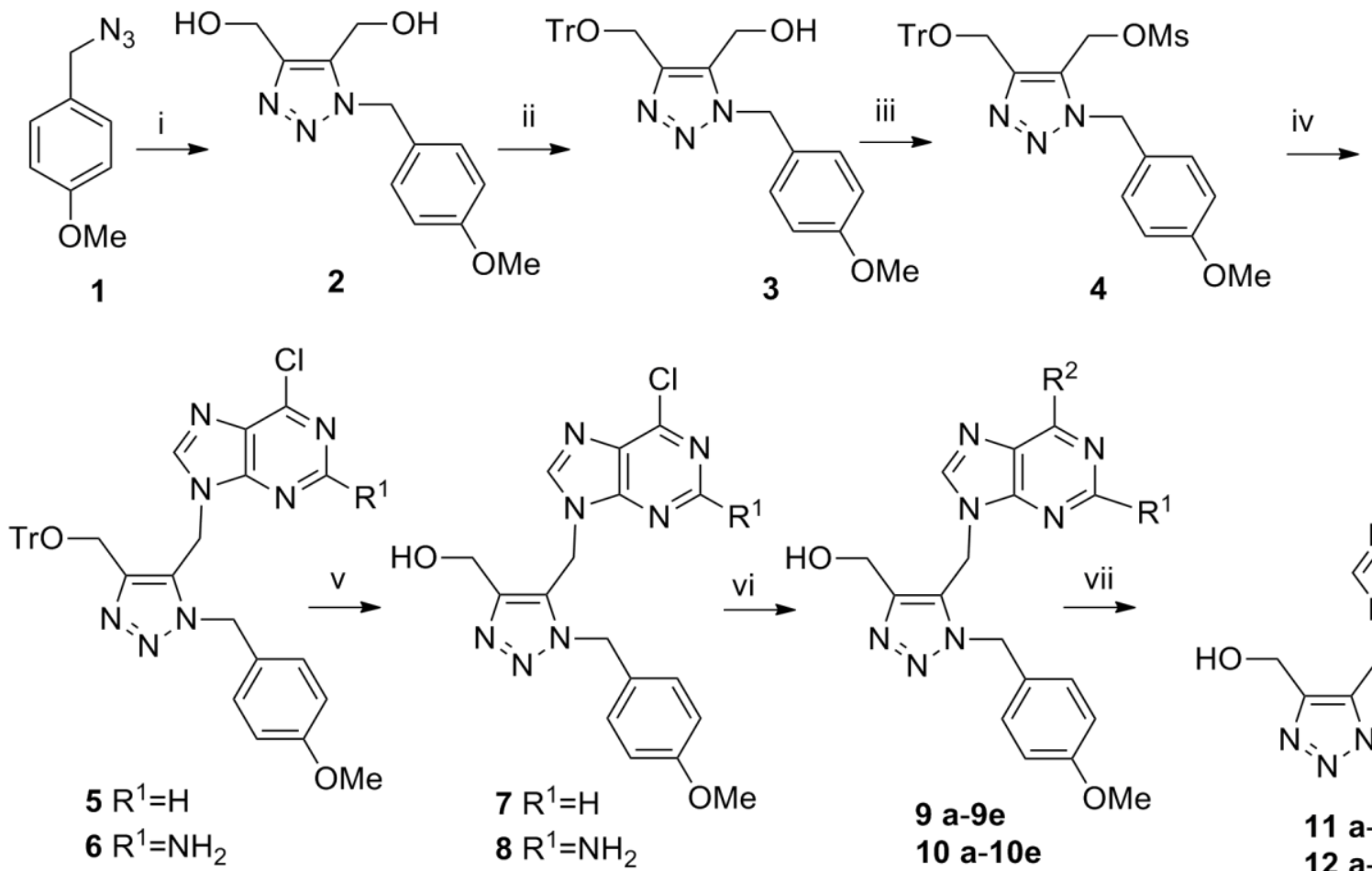

$$
\begin{aligned}
& \text { 9a } \mathrm{R}^{2}=\mathrm{NHCH}_{3}, \mathrm{R}^{1}=\mathrm{H} \quad 10 \mathrm{a} \mathrm{R}^{2}=\mathrm{NHCH}_{3}, \mathrm{R}^{1}=\mathrm{NH}_{2} \\
& \text { 9b R } \mathrm{R}^{2}=\mathrm{NH}_{2}, \mathrm{R}^{1}=\mathrm{H} \quad 10 \mathrm{~b} \mathrm{R}^{2}=\mathrm{NH}_{2}, \quad \mathrm{R}^{1}=\mathrm{NH}_{2} \\
& \text { 9c } \mathrm{R}^{2}=\mathrm{HN} \longrightarrow \mathrm{R}^{1}=\mathrm{H} 10 \mathrm{c} \mathrm{R} \mathrm{R}^{2}=\mathrm{HN} \longrightarrow \mathrm{R}^{1}=\mathrm{NH}_{2} \\
& \text { 9d } \mathrm{R}^{2}=\mathrm{OMe}, \mathrm{R}^{1}=\mathrm{H} \quad 10 \mathrm{~d} \mathrm{R}^{2}=\mathrm{OMe}, \mathrm{R}^{1}=\mathrm{NH}_{2} \\
& \text { 9e } R^{2}=\mathrm{OEt}, \mathrm{R}^{1}=\mathrm{H} \quad \text { 10e } \mathrm{R}^{2}=\mathrm{OEt}, \mathrm{R}^{1}=\mathrm{NH}_{2}
\end{aligned}
$$
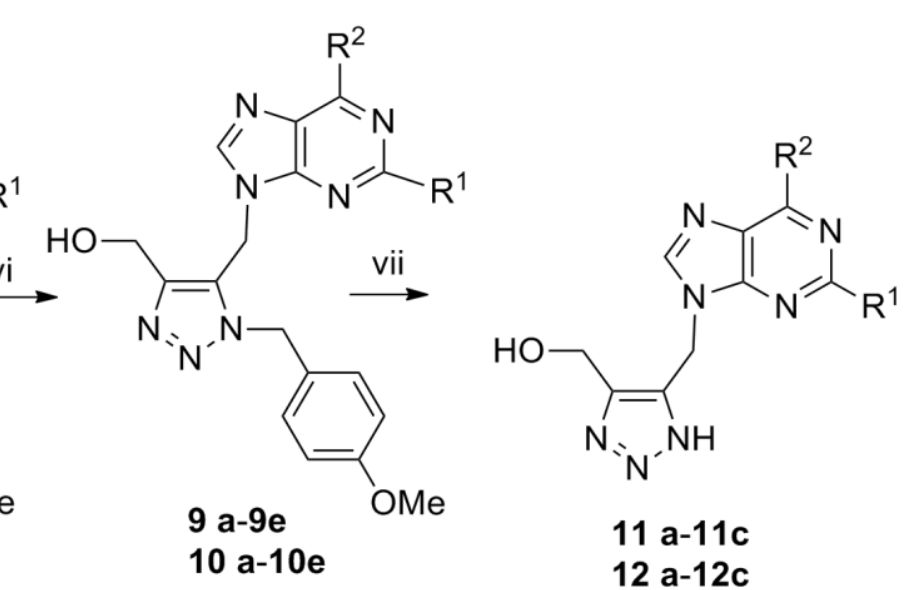

Scheme 1 Reagents and conditions: i) 2-Butyne-1,4-diol, tolune, $110^{\circ} \mathrm{C}, 90 \%$; ii) $\mathrm{TrCl}_{1} \mathrm{Et}_{3} \mathrm{~N}, \mathrm{CH}_{2} \mathrm{Cl}_{2}, 0^{\circ} \mathrm{C}, 85 \%$; iii) $\mathrm{MsCl}_{3} \mathrm{Et}_{3} \mathrm{~N}$, $\mathrm{CH}_{2} \mathrm{Cl}_{2}, 0^{\circ} \mathrm{C}, 90 \%$; iv) 6-chloro-purine, $\mathrm{K}_{2} \mathrm{CO}_{3}, \mathrm{DMF}$, rt, 60\%; v) 6-Chloroguanine, $\mathrm{K}_{2} \mathrm{CO}_{3}, \mathrm{DMF}, \mathrm{rt}, 65 \%$; vi) $\mathrm{CF}_{3} \mathrm{COOH} \mathrm{CH}_{2} \mathrm{Cl}_{2}$, rt, 75\%; vii) a) $\mathrm{CH}_{3} \mathrm{NH}_{2} / \mathrm{EtOH}, 60^{\circ} \mathrm{C}, 65 \%$; b) $\mathrm{NH}_{3} \mathrm{H}_{2} \mathrm{O} / \mathrm{EtOH}, 60^{\circ} \mathrm{C}, 74 \%$; c) cyclopropylamine, $\mathrm{EtOH}, 60^{\circ} \mathrm{C}, 70 \%$; d) $\mathrm{MeONa}$, $\mathrm{MeOH}, 60^{\circ} \mathrm{C}, 75 \%$; e) EtONa, EtOH, $60^{\circ} \mathrm{C}, 80 \%$; ix) $\mathrm{CF}_{3} \mathrm{COOH}$, reflux, $70 \%$.

\section{REFERENCES}

[1] Jin-Lan Yu, Qin-Pei Wu, Qing-Shan Zhang, Yan-Hong Liu b, Yun-Zheng Li \& Zi-Ming Zhou. 2010. Synthesis and antitumor activity of novel 2',3' -dideoxy-2',3'diethane thionucleosides bearing 1,2,3-triazole residues, Bioorganic and \& Medicinal Chemistry Letter, (20)240243.

[2] (a) Paulo M. Hoff, Rafat Ansari, Gerald Batist, John Cox .et al. 2001. Comparison of Oral Capecitabine Versus Intravenous Fluorouracil Plus Leucovorin as First-Line Treatment in 605 Patients With Metastatic Colorectal Cancer: Results of a Randomized Phase III Study. Journal of Clinical Oncology (15)2282-2292. (b) D C Talbot, V Moiseyenko, S Van Belle, S M O'Reilly, E Alba Conejo, S Ackland, P Eisenberg, D Melnychuk, T Pienkowski, H-U Burger, S Laws \& B Osterwalder. 2002. Randomised, phase II trial comparing oral capecitabine (Xeloda $\left.{ }^{\circledR}\right)$ with paclitaxel in patients with metastatic/advanced breast cancer pretreated with anthracyclines. British Journal of Cancer. (86)1367-1528.

[3] Genini D, Adachi S, Chao Q, Rose DW, Carrera CJ, Cottam HB, Carson DA \& Leoni LM. 2000. Deoxyadenosine analogs induce programmed cell death in chronic lymphocytic leukemia cells by damaging the DNA and by directly affecting the mitochondria. Blood (96)3537-3543.

[4] H G Chun, B Leyland-Jones \& B D Cheson. 1991. Fludarabine phosphate: a synthetic purine antimetabolite with significant activity against lymphoid malignancies. Journal of Clinical Oncology (9) 175-178.

[5] S Lindemalm, J Liliemark, A Gruber, S Eriksson, MO Karlsson, Y Wang \& F Albertioni. 2003. Comparison of cytotoxicity-of-2-chloro-2'-arabino-fluoro-2'-

deoxyadenosine (clofarabine) with cladribine in mononuclear cells from patients with acute myeloid and chronic lymphocytic leukemia. Haematologica 88 (3)324332.

[6] Jin-Lan Yu, Qin-Pei Wu, Qing-Shan Zhang.et al. 2010. Synthesis and antitumor activity of novel 2',3'diethanethio-2',3',5'-trideoxy-5'-triazolonucleoside analogues. European Journal of Medicinal Chemistry. (45)3219-3222.

[7] Thirumurugan P, Matosiuk D \& Jozwiak K. 2013. Click Chemistry for Drug Development and Diverse ChemicalBiology Applications. Chemical Reviews. 113(7) 49054979.

[8] Kini G D, Robins R K \& Avery T L. 1989. Synthesis and antitumor activity of ribavirin imidates. New facile synthesis of ribavirin amidine (1-.beta.-D-ribofuranosyl 1,2,4-triazole-3-carboxamidine hydrochlo- ride). Journal of Medicinal Chemistry, 32(7)1447-1449.

[9] B E Gilbert \& V Knight. 1986. Biochemistry and clinical applications of ribavirin. Antimicrobial Agents and Chemotherapy. (30)201-205.

[10] Wei-Yong Liu, Hai-Ying Li .et.al. 2009. Synthesis of novel ribavirin hydrazone derivatives and antiproliferative activity against A549 lung cancer cells. 
Carbonhydrate Research. (344)1270-1275.

[11] Antonino Lauria, Riccardo Delisi .et.al. 2014. 1,2,3Triazole in Heterocyclic Compounds, Endowed with Biological Activity, through 1,3-Dipolar Cycloadditions. European Journal of Medicinal Chemistry. 3289-3306.
[12] Amblard F \& Cho J H, Schinazi R F. 2009. Cu(I)Catalyzed Huisgen Azide-Alkyne 1,3-Dipolar Cycloaddition Reaction in Nucleoside, Nucleotide, and Oligonucleotide Chemistry. Chemical Reviews, 109(9), 4207-4220. 